\title{
Water Carrying Capacity Approach in Spatial Planning: Case Study at Malang Area
}

\author{
Arief Riyadi ${ }^{1}$, Arief Rachmansyah ${ }^{2}$, Bagyo Yanuwiadi ${ }^{3}$ \\ ${ }^{1}$ Post Graduate School of Environmental and Developmen, Graduate Program, Brawijaya University, Malang, Indonesia \\ ${ }^{2}$ Civil Engineering Department, Faculty of Engineering, Brawijaya University, Malang, Indonesia \\ ${ }^{3}$ Biology Department, Faculty of Mathematic and Science, Brawijaya University, Malang, Indonesia
}

\begin{abstract}
The Law of the Republic of Indonesia Number 32 of 2009 and 26 of 2007 affirms that need environmental carrying capacity in preparation of regional spatial plans. The Great Malang bypassed 12 sub-watershed which is 4 of them pass 3 regency / city directly. Therefore, it needs an integrated spatial arrangement between the three regions. The purpose of this research is to formulate study of water carrying capacity (WCC) and recommendation for input in spatial planning in Malang area. The results of the water carrying capacity study show that Metro and the Bango Sub-watershed is very worrying because its critical condition has been exceeded before 2015. While the Amprong and Manten sub-waters are still safe until 2030.
\end{abstract}

Key word: Amprong, Bango, Manten, Metro, Sub-watershed, Water carrying capacity

\section{INTRODUCTION}

Upper Brantas Watershed (DAS), which passes through Batu City, Malang City and Malang Regency, is a very important part in providing raw water for community in Malang and East Java. There are several PDAMs that utilize Brantas River as raw water for clean water treatment. The survey conducted by Ecoton with the Dutch International Ecosystem Grant Program (EGP) [1] shows that the number of springs in the Upper Brantas watershed area is decreasing. Investigations conducted in Toyomarto village, Mount Kawi and Mount Arjuno clearly indicate the narrowing of the springs and even the missing ones. Therefore, holistic and sustainable conservation efforts need to be done by the stakeholders in these three areas so that the Upper Brantas watershed will be maintained.

A study on WCC comes as a bridging tool between land needs and land availability, between water demand and water availability, food needs and food availability in a region. It is hoped that this study will provide input to policy makers, programs and activities in a sustainable spatial planning in Malang Area.

\section{Definition of Environmental Carrying Capacity}

The definition of environmental carrying capacity in an ecological context is the number of populations or communities that can be supported

\footnotetext{
Correspondence address:

Arief Riyadi

Email : rayhanbiwiz@gmail.com

Address : Post Graduate School of Environmental and Developmen, Graduate Program, Brawijaya University, Malang, Indonesia
}

by the resources and services available within the ecosystem [3]. Factors affecting the limitations of ecosystems to support livelihoods are the number of available resources, the number of populations and their consumption patterns.

\section{Basic Formulation of Environmental Carrying Capacity \\ The environmental carrying capacity is} divided into 2 components, namely the capacity of supportive capacity and the capacity of waste (assimilative capacity) [4]. The environmental carrying capacity is limited to the capacity to supply natural resources, especially with regard to land capacity and the availability and demand for land and water in a space/area.

\section{Comparative Methods of Water Supply and Availability}

This method shows how to calculate the carrying capacity of water in a region, taking into account the availability and the need for water resources for the people living in the area. With this method, it can be known generally whether the water resources in a region in a surplus or deficit. The surplus state indicates that the availability of water in a region is sufficient, while the deficit state indicates that the region is unable to meet the water needs. In order to meet water needs, the environmental functions associated with the water system must be preserved.

Steps to calculate water carrying capacity as follows:

1. Calculation of Water Suppy (SA)

The calculation using modified run-off coefficient from rational method as follows: 


$$
\begin{aligned}
& C=\frac{\sum(C i x A i)}{\sum_{A i}} \\
& R=\frac{\sum(R i)}{m} \ldots \ldots \ldots \ldots \\
& S A=10 x C x \text { R } x A
\end{aligned}
$$

If $\mathrm{DDA}>3$, water carrying capacity status is good.

The aims of this study are:

1. To formulate water carrying capacity study in Malang area

2. Formulate recommendations for

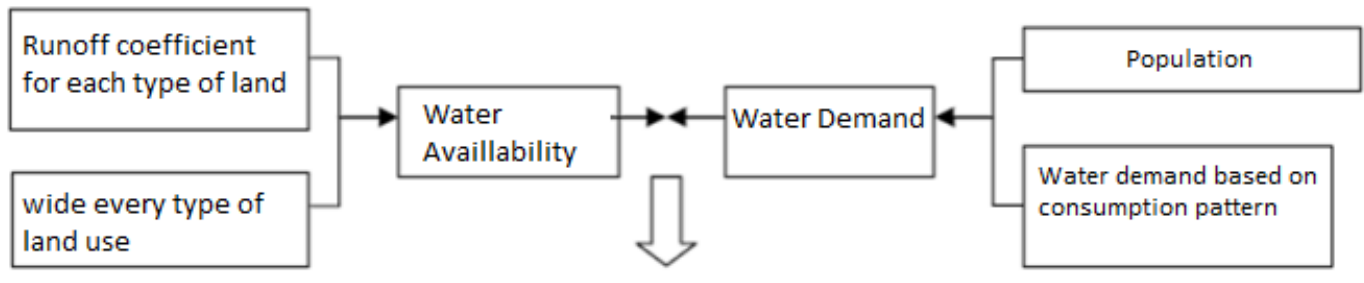

Water Carrying Capacity

Figure 1 Concepts of WCC

Description:

$\mathrm{SA}=$ Water Supply (m3/year)

$\mathrm{C}=$ weighted runoff coefficient

$\mathrm{Ci}=$ land use runoff coefficient $\mathrm{i}$

$\mathrm{Ai}=$ wide land use $\mathrm{I}$ (ha)

$\mathrm{R}=$ average annual algebraic rainfall area (mm/year)

$\mathrm{Ri}=$ annual rainfall in station $\mathrm{i}$

$m=$ number of rainfall observation stations

$A=$ wide area (ha)

$10=$ conversion factor from $\mathrm{mm}$.ha to $\mathrm{m}^{3}$

2. Calculation of Demand Water (DA)

$\mathrm{DA}=\mathrm{N} \times \mathrm{KHLA}$

Where as:

$\mathrm{DA}=$ Total water needs (m3/year)

$\mathrm{N} \quad$ = number of people (person)

$\mathrm{KHLA}=$ Water needs to live worthy

$=1600 \mathrm{~m}^{3} /$ capita/year,

$=2 \times 800 \mathrm{~m}^{3}$ /cap/year, whereas:

$800 \mathrm{~m}^{3}$ /cap/year is the need for water for domestic purposes and to produce food.

2.0 is corrective factor to calculate the needs of live worthy, including the needs of food, domestic purpose and others.

3. Determination of WCC Status

The WCC obtained from the comparison between water availability (SA) and water requirements (DA) is as follows:

DDA $=S A / D A$

If $D D A<1$, water carrying capacity status is exceeded or poor

If DDA 1-3, water carrying capacity status is medium or conditional. spatial planning input in Malang area

The scope of this study is the carrying capacity of surface water derived from the absorption of rainwater compared with clean water to meet domestic needs. Domestic water demand will grow in line with population growth. For non-domestic water needs, such as industry, is predicted to show a declining trend [2]. This condition is due to transfer of technology applied to the factory so it will save the use of clean water. The water needs for agriculture shows a relatively more stable trend up to 15 years to come.

\section{RESEARCH METHOD}

This type of study is quantitative-descriptive by comparing water requirements for domestic consumption with the availability of water in a field, calculated by the principle of rainwater infiltration in a region. While the water demand is calculated by water demand of each population multiplied by the number of population. The calculation results show a positive number (water surplus) and negative (water deficit). This will be an input in preparing spatial planning in Great Malang. This study located in Metro, Amprong, Bangosari Sub-watershed and Manten Subwatershed.

Table 1 Area of Study

\begin{tabular}{cllll}
\hline No & $\begin{array}{l}\text { Name of Sub } \\
\text { Watershed }\end{array}$ & $\begin{array}{l}\text { Wide } \\
\mathbf{( k m}^{\mathbf{2}} \mathbf{n}\end{array}$ & $\begin{array}{l}\text { Length } \\
\mathbf{( \mathbf { k m } )}\end{array}$ & Location \\
\hline 1 & Kali Bangosari & 235 & 12,5 & Malang \\
2 & Kali Metro & 399 & 25 & Malang \\
3 & Kali Amprong & 349 & 20,5 & Malang \\
4 & Kali Manten & 176 & 9,8 & Malang \\
\hline
\end{tabular}

Source: BBWS 


\section{Description of Area Study}

Brantas river watershed classified into 36 sub watershed and bypasses 9 districts/cities in East Java. Location of study as follow in tabel 1 and figure 2

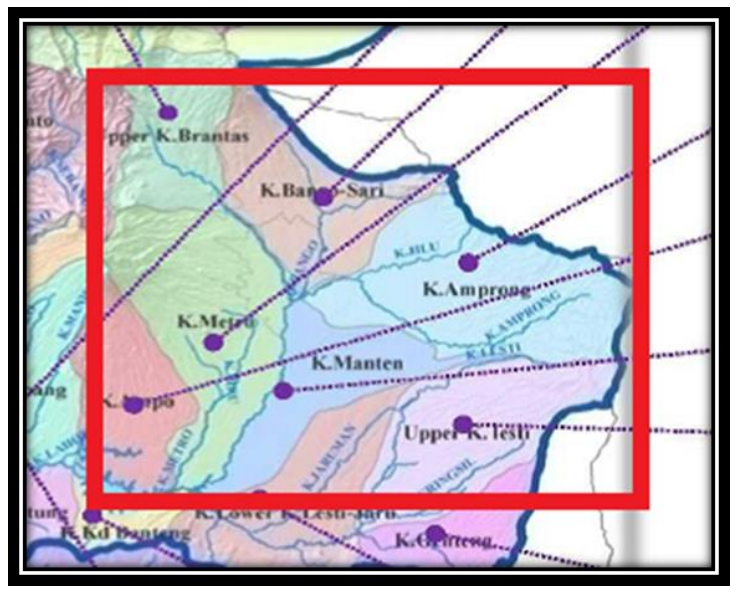

Figure 2 Area of Study

\section{RESULT AND DISCUSSION \\ Projection Population}

The calculation of population projection using gemotri method, as follows:

Table 2 Projection Population in each Sub Watershed

\begin{tabular}{lllll}
\hline $\begin{array}{l}\text { Sub } \\
\text { Watershed }\end{array}$ & $\begin{array}{l}\text { Number } \\
\text { of Pop. } \\
\text { In 2015 }\end{array}$ & $\begin{array}{l}\text { Number } \\
\text { of Pop. } \\
\text { In 2020 }\end{array}$ & $\begin{array}{l}\text { Number } \\
\text { of Pop. In }\end{array}$ & $\begin{array}{l}\text { Number } \\
\text { of Pop. In }\end{array}$ \\
\hline Metro & 452,044 & 482,007 & 515,767 & 552,416 \\
Bango & 571,664 & 669,668 & 716,400 & 767,424 \\
Amprong & 294,290 & 316,824 & 341,869 & 369,747 \\
Manten & 261,826 & 272,043 & 282,689 & 293,781 \\
\hline
\end{tabular}

Source: Result of Analysis, 2017

\section{Supply and Demand Analysis}

Figure 3 shows the comparison between water availability and water demand in each sub-basin. From the figure it can be seen that Metro (a) and Bango (b) Sub-watersheds are in an alarming condition, as water availability is less than the water requirement in the area. Even critical conditions have been exceeded before 2015. So there is an urgent need to increase water carrying capacity. While the Amprong and Manten subwatershed is safe until 2030.

Overall, the condition of WCC in the Metro subwatershed is alarming. By 2015 there were 33 villages (55\%) whose WCC is poor. This number continues to grow until 2030 so that $70 \%$ of the village area along the Metro sub-watershed in the category exceeded or poor. This situation will continue to deteriorate as water demand tends to increase, while water availability tends to stagnate [4]. Thus, the possibility of conditional safe conditions will turn out to be poor at some point, if not accompanied by efforts to strengthen the WCC along the sub-watershed

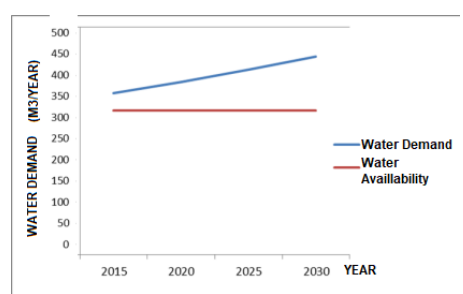

(a)

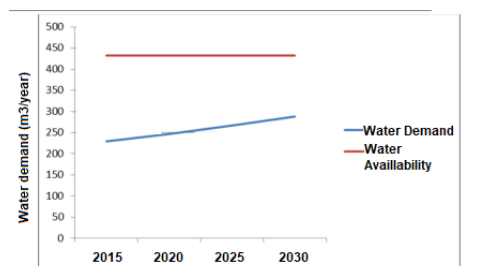

(d)

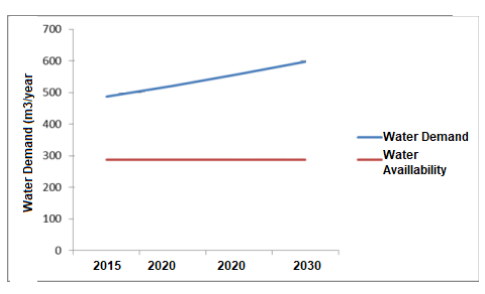

(b)

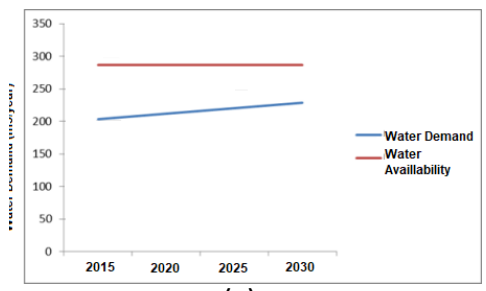

(c)
Figure 3. Comparison of water requirements and Water Availability in Metro sub-watershed (a), Bango Sub-watershed (b), Amprong Sub-watershed (c) and Manten Sub-watershed (d)

Status of Water Carrying Capacity

The status of WCC can be shown in table 3 .

Table 3 The WCC Status of Metro Sub-watershed

\begin{tabular}{lcccc}
\hline \multirow{2}{*}{ Status } & $\mathbf{5}$ & \multicolumn{3}{c}{ Year } \\
& $\mathbf{2 0 1 5}$ & $\mathbf{2 0 2 0}$ & $\mathbf{2 0 2 5}$ & $\mathbf{2 0 3 0}$ \\
\hline GOOD & 3 & 2 & 2 & 2 \\
MEDIUM & 24 & 22 & 20 & 16 \\
POOR & 33 & 36 & 38 & 42 \\
TOTAL & $\mathbf{6 0}$ & $\mathbf{6 0}$ & $\mathbf{6 0}$ & $\mathbf{6 0}$ \\
\hline
\end{tabular}

Source: Result of Analysis, 2017

Table 4 The WCC Status of Bango Sub-watershed

\begin{tabular}{lllll}
\hline \multirow{2}{*}{ Status } & \multicolumn{4}{c}{ Year } \\
& $\mathbf{2 0 1 5}$ & $\mathbf{2 0 2 0}$ & $\mathbf{2 0 2 5}$ & $\mathbf{2 0 3 0}$ \\
\hline GOOD & 3 & 2 & 2 & 1 \\
MEDIUM & 7 & 8 & 8 & 8 \\
POOR & 41 & 41 & 41 & 42 \\
TOTAL & $\mathbf{5 1}$ & $\mathbf{5 1}$ & $\mathbf{5 1}$ & $\mathbf{5 1}$ \\
\hline
\end{tabular}

Source: Result of Analysis, 2017

Table 5 shows that poor WCC status will be occur in 42 villages (82.35\%) to 2030. This situation is caused by land use along the Bango sub-basin shows $37.16 \%$ has turned into settlements and industries. The poor WCC location is concentrated in Pendem Village in Batu City, all Malang City, Pakis Sub-district, 75\% Karangploso Sub-district and $58.82 \%$ Singosari Sub- district.

The WCC status of Amprong sub-watershed is relatively stable until 2030 . The number of villages 
with poor water carrying capacity or deficit increased $38.77 \%$ (2015) to $40.81 \%$ (2030). This situation is supported by forest area along Jabung and Poncokusumo sub-districts the surroundings Mount Bromo. The WCC status of poor or deficit is concentrated in Malang City and Pakis District. The poor WCC is due to the location of Pakis subdistrict as the buffer zone of Malang City, so that the impact of settlement growth. Land use status indicates that $37.16 \%$ of land along the Amprong Sub-watershed has become settlements.

Table 6 The WCC Status of Amprong Subwatershed

\begin{tabular}{lllll}
\hline \multirow{2}{*}{ Status } & \multicolumn{4}{c}{ Year } \\
& $\mathbf{2 0 1 5}$ & $\mathbf{2 0 2 0}$ & $\mathbf{2 0 2 5}$ & $\mathbf{2 0 3 0}$ \\
\hline GOOD & 13 & 12 & 12 & 11 \\
MEDIUM & 17 & 18 & 17 & 18 \\
POOR & 19 & 19 & 20 & 20 \\
TOTAL & 49 & 49 & 49 & 49 \\
\hline
\end{tabular}

Source: Result of Analysis, 2017

Tabel 7 The WCC Status of Manten Sub-watershed

\begin{tabular}{lllll}
\hline \multirow{2}{*}{ Status } & \multicolumn{4}{c}{ Year } \\
& $\mathbf{2 0 1 5}$ & $\mathbf{2 0 2 0}$ & $\mathbf{2 0 2 5}$ & $\mathbf{2 0 3 0}$ \\
\hline GOOD & 2 & 2 & 1 & 1 \\
MEDIUM & 37 & 36 & 35 & 32 \\
POOR & 9 & 10 & 12 & 15 \\
TOTAL & 48 & 48 & 48 & 48 \\
\hline
\end{tabular}

Source: Result of Analysis, 2017

It can be seen in table 7, that from 2015 to 2030 the WCC decreases regularly. The number of villages with poor WCC increased from 18.75\% (2015) to $42.85 \%$ (2030). The location of villages with poor WCC is concentrated in Kecamatan Kepanjen, Gondanglegi and Bululawang. This situtaion is the impact of the development of Kepanjen District into the capital of Malang Regency, so the migration flow and population growth is higher than the surrounding districts. Land use status showed that the land becomes settlement in Manten Sub-watershed grows to $20.31 \%$.

Many factors that may affect WCC are:

1. Land area and Rainfall. Area with high rainfall and large areas will have a high availability of meteorological water as well as reverse conditions [5]

2. Run-off Coefficient. The runoff coefficient is a number that shows the comparison between the amounts of runoff water to the amount of rainfall [6].

3. Land Use Changing. Land use change for settlements and other uses will reduce the infiltration of rainwater into the soil [7]. Land use in the upstream area (Batu City) of 25-26\% is not in accordance with the allocation [8] and [9]. As a result, the coefficient of the river regime shows the category of "very bad" because the ratio between the maximum and minimum discharge exceeds 120 [10]

4. Population Growth and Its Distribution. There is an imbalance between the rate of population growth and the pattern of its distribution with the dissemination of natural resources and the carrying capacity of the existing environment. This condition triggers the destruction of natural resources and the environment [11].

\section{CONCLUSION AND RECOMMENDATION}

The concusion of this study as follows :

1. Status of WCC in Metro and Bango Subwatersheds is very worrying because the critical condition has been exceeded before 2015. So urgent need serious attention and handling of the three policy makers in Great Malang to overcome water crisis in the future. Meanehile, Amprong and Manten subwatersheds are still safe until 2030.

2. Spatial planning recommendations for areas with poor WCC are as follows [12]:

- Expanding Green Open Space by either overturning rice fields as green open space (RTH) or encouraging local governments to buy rice fields and making RTH, encouraging people to manage private space into green open space, optimizing government-owned land and buildings as an ideal green open space model; Establish private RTHs in high rise buildings and dense areas with hanging gardens, vertical gardens and potted plants

- Holding the Rate of Land Use Changing by arranging the regulation for horizontal housing development, settlement arrangement around riverbanks and other slums, returns the function of river banks as rainwater catchment area by planting vegetation stands

- Restoring Rainwater into the Soil by means of: making rain water catchment in the building basement, absorption well, biopori and eco-drainage

- Water use savings by: domestic wastewater treatment and reuse, tariff setting more progressive, recognizing technical and non technical leakage, reward and punishment to water customers.

3. The spatial planning recommendation for areas with medium to poor WCC or good to medium is as follows [13]: 
- Vegetative Conservation. Conservation of this species is suitable for plantation and forest land, or in protected areas around the spring with a radius of $200 \mathrm{~m}$.

- Mechanical Conservation. Mechanical conservation is all physical, mechanical and building work done in the land, aimed at reducing run-off, erosion and improving soil skills classes. One method that is done is making the terraces on sloped land.

- Constructive Conservation. The type of conservation can be done with several alternatives, like: making absorption wells, and check dam, pond absorption (embung), eco-drainage channel, and biopori. In areas where the topography is flat and located in residential areas can implement absorption wells. Meanwhile, the upstream areas of the hills better apply the system of pond absorption (embung). The development of embung in Karangploso Subdistrict (1 unit of embung), Singosari Sub-district (3 pieces of embung) and Kedungkandang Subdistrict (1 artificial lake) [1]

\section{ACKNOWLEDGEMENT}

This study is part of the project "Strategic Environmental Assesment (KLHS)" funded by District Planning and Development Agency (Bappeda) of Malang District.

\section{REFERENCES}

[1]. Solikhati, Ima., Harisuseno, Donny., Suhartanto, Ery. 2013. Studi Identifikasi Indeks Kekeringan Hidrologis Pada Daerah Aliran Sungai (DAS) Berbasis Sistem Informasi Geografis (SIG) (Studi Kasus pada DAS Brantas Hulu : Sub-DAS Upper Brantas, Sub-DAS Amprong dan Sub-DAS Bangosari).

[2]. Liao, Hongyan., Zhang, Yuabiao., Chen, Zhifeng., Meng, Zexin. 2017. "Evaluation and Prediction of Regional Water Resources Carrying Capacity: A Case Study of Shandong Province". Environment and Natural Resources Research; Vol. 7, No. 1; 2017. ISSN 1927-0488 E-ISSN 1927-0496. Published by Canadian Center of Science and Education

[3]. Rees, Judith, A review of: "Natural Resources: Allocation, Economics and Policy", New York, Routledge Chapman and Hall, 1990

[4]. Brontowiyono, Widodo. 2016. KLHS untuk RTRW dengan Pendekatan Daya Dukung Lingkungan. Yogyakarta

[5]. Admadhani, Dianindya Novita., Haji, Alexander Tunggul Haji., Susanawati, Liliya
Dewi. 2014. “Analisis Ketersediaan Dan Kebutuhan Air Untuk Daya Dukung Lingkungan (Studi Kasus Kota Malang)". Jurnal Sumberdaya Alam dan Lingkungan

[6]. Alimin, Muhammad. 2015. Estimasi Limpasan Permukaan DAS Mikro Brantas Hulu Kecamatan Bumiaji Kotabatu Menggunakan Penginderaan Jauh Dan System Informasi Geografis. Jurnal Tanah dan Sumberdaya Lahan Vol 2 No 2 :171-177, 2015

[7]. Wiwoho, Bagus Setiabudi, 2008. "Analisis Potensi Daerah Resapan Air Hujan Di Sub DAS Metro Malang Jawa Timur". MIPA, Tahun 37, Nomor 1, Januari 2008, hlm. 91-96

[8]. Putra, Agus Maulana. 2013."Penentuan Daya Dukung Lingkungan Berbasis Neraca Lahan Tahun 2013 Di Kota Batu". Dalam Jurnal Sumberdaya Alam dan Lingkungan

[9]. Rahardi, Bambang., Anugroho, Fajri., Nurlaelih, Euis Elih., Lusiana, Novia., Sulianto, Akhmad Adi. 2017. "Assessment of The Impacts Of Land Use On Water Quality Of Brantas Upstream, Batu City, Indonesia". Journal of Environmental Engineering \& Sustainable Technology (JEEST) Vol. 04 No. 01, July 2017

[10]. Riskihadi, Afrike., Rahardi, Bambang., Suharto, Bambang. 2014."Penentuan Kinerja Sub Das Junggo Dalam Pengelolaan Daerah Hulu DAS Brantas". Dalam Jurnal Sumberdaya Alam dan Lingkungan

[11]. Rofiana, Vifin. 2015. “Dampak Pemukiman Kumuh Terhadap Kelestarian Lingkungan Kota Malang (Studi Penelitian di Jalan Muharto Kel Jodipan Kec Blimbing, Kota Malang)", IJPA-The Indonesian Journal of Public Administration Volume 2 Nomor 1 Nopember 2015

[12]. Widodo, B. Lupyanto, R., Sulistiono, R., Harjito D. A., Hamidin, J., Hasari E., Yasin M., Ellinda, C. 2015. "Analysis of Environmental Carrying Capacity For The Development of Sustainable Settlement In Yogyakarta Urban Area". Procedia Environmental Sciences 28 (2015) 519-527

[13]. Kustamar, Parianom, Bambang., Sukowiyono, Gaguk., Arniati, Tutik. 2010. "Water Source Conservation Based Upon Community's Participation In Batu Town, East Java. Dinamika TEKNIK SIPIL/Vol. 10/No. 2/Mei 2010/Halaman : 144-149

[14]. Peraturan Menteri Negara Lingkungan Hidup Nomor 17 Tahun 2009 Tentang Pedoman Penentuan Daya Dukung Lingkungan Hidup Dalam Penataan Ruang Wilayah 
[15]. Undang Republik Indonesia Nomor 32 Tahun 2009 tentang Perlindungan dan Pengelolaan Lingkungan Hidup

[16]. Undang-Undang Republik Indonesia Nomor 28 Tahun 2007 tentang Penataan Ruang 